\title{
Pre-Service Teachers' Self-Efficacy and Attitudes Regarding Using Motifs from Neuroeducation in Education and Teaching
} Efrat Luzzatto \& Alina S. Rusu 


\title{
Pre-Service Teachers' Self-Efficacy and Attitudes Regarding Using Motifs from Neuroeducation in Education and Teaching
}

\author{
Efrat Luzzato ${ }^{\text {a*, }}$, Alina S. Rusu ${ }^{b}$ \\ ${ }^{a}$ Doctoral School "Educational, Reflection, Development", Babeș-Bolyai University, 7 Sindicatelor Street, Cluj-Napoca, 400029, Romania \\ ${ }^{b}$ Department of Special Education, Faculty of Psychology and Educational Sciences, Babeș-Bolyai University, 7 Sindicatelor Street, Cluj-Napoca, \\ 400029, Romania \\ *Corresponding author:efratluz@gmail.com
}

Abstract

Keywords:

Neuroeducation,

Teacher Self- Efficacy, Attitudes toward

Change, Pre-Service Teachers.
Neuroeducation is defined as a growing interdisciplinary field based on the synergic connection between neuroscience, cognitive science, psychology and education to improve the theoretical and practical understanding of learning and education. Besides the characteristics of the learners, the process of implementation of an innovative approach such as neuroeducation in the classroom involves psycho-social characteristics of the educators, such as teacher self-efficacy and attitudes toward change. The aim of this research was to explore which factors may explain the variance in pre-service teacher's attitudes towards using concepts from neuroeducation in education and teaching. Thirty-three Israeli pre-service teachers (PSTs) who participated in a neuroscience training program filled out a battery of questionnaires targeting their self-efficacy and attitudes toward change. A regression analysis revealed a positive correlation between PSTs' roles regarding combining neuroscience in education, the amount of time they are willing to invest in introducing change in their teaching methods and attitudes toward change in combining knowledge from neuroscience in education. Also, a negative correlation between PSTs' self-efficacy and attitudes toward change regarding combining knowledge from neuroscience in education was found. Possible explanations and the contribution to knowledge were discussed.

\section{Zusammenfasung}

\section{Schlüsselworte:}

Neuropädagogik, Selbstwirksamkeit der Lehrer,

Einstellungen gegenüber

Veränderungen, Pre-

Service-Lehrer

(Lehrer vor dem

Dienst).
Neuropädagogik wird als ein wachsendes interdisziplinäres Feld definiert, das auf der synergetischen Verbindung von Neurowissenschaften, Kognitionswissenschaft, Psychologie und Bildung beruht, um das theoretische und praktische Verständnis von Lernen und Bildung zu verbessern. Neben den Merkmalen der Lernenden beinhaltet der Umsetzungsprozess eines innovativen Ansatzes wie der Neurpädagogik im Klassenzimmer auch psychosoziale Merkmale der Pädagogen wie die Selbstwirksamkeit des Lehrers und die Einstellung gegenüber Veränderungen. Das Ziel dieser Forschung war es, herauszufinden, welche Faktoren die Unterschiede in der Einstellung des Pre-Service-Lehrers zur Verwendung von Konzepten aus der Neurpädagogik in Bildung und Unterricht erklären können. Dreiunddreißig israelische Pre-Service-Lehrer (PSTs), die an einem neurowissenschaftlichen Schulungsprogramm teilgenommen haben, füllten eine Reihe von Fragebögen aus, die auf ihre Selbstwirksamkeit und ihre Einstellung gegenüber Veränderungen abzielten. Eine Regressionsanalyse ergab eine positive Korrelation zwischen den Rollen von PSTs in Bezug auf die Kombination von Neurowissenschaften in der Bildung, der Zeit, die sie bereit sind, in die Einführung von Änderungen in ihren Lehrmethoden zu investieren, und der Einstellung gegenüber Änderungen bei der Kombination von Wissen aus Neurowissenschaften in der Bildung. Es wurde auch eine negative Korrelation zwischen der Selbstwirksamkeit von PSTs und der Einstellung zur Kombination von Wissen von Neurowissenschaften (NS) in der Bildung gefunden. Mögliche Erklärungen und der Beitrag zum Wissen wurden diskutiert.

\section{Introduction}

In recent years, a growing number of researchers in the field of sciences of education have manifested interest in developing a new science of learning that can contribute to evidence-based policies and practices in education (e.g., Ansari, DeSmedt, \& Grabner, 2012; Meltzoff, Kuhl, Movellan, \& Sejnowski, 2009). Neuroeducation is defined as a growing interdisciplinary field based on the synergic connection between neuroscience (NS), cognitive science, psychology and education in an effort to improve the theoretical and practical understanding of learning and education (Devonshire \& Dommett, 2010; Nouri, 2013; Rodgers, 2015). So far, only few studies have investigated the implementation of neuroeducation in practice.

Changing teachers' practices by including elements of neuroeducation might take time and requires ongoing professional development and support. Thus, there is merit to the idea that adoption and diffusion of an 
innovation or practice is tied to self-efficacy. Since neuroeducation (NE) is a relatively new discipline, there is a gap in the research between NE as a broader discipline and how it infiltrates the school settings, or specifically how motifs from the neuroeducation field are implemented in the classroom. It is essential to explore how educators apply and assess the NE-grounded approaches they utilize in the classroom, and the role that self-efficacy plays. Therefore, teacher self-efficacy in general and specifically in implementing motifs from NE in classes was targeted in this study, with the participation of pre-service teachers (PSTs). It was assumed that PSTs' self-efficacy may increase through mastery experiences, gained through perseverant effort and accompanied by feedback from others in a non-threatening environment indicating that the pre-service teachers possess certain levels of capability (Bandura 2006, in Van der Linden et. al, 2015). Specifically, this paper presents the findings of a quantitative study conducted among PSTs in Israel, who participated in a teacher-training program based on NE motifs. The psycho-social characteristics of the preservice teachers may have a mediating role between what they acquired in the training program and the implementation of the acquired knowledge in the lessons.

\section{Theoretical foundations}

According to the neuroeducation principles, knowledge of the brains' functions involved in the learning process could impact educational strategies to promote efficient learning. This is due to understanding brain mechanisms that regulate learning and memory processes (Blakemore \& Frith, 2005). Implementation of this knowledge in the education system requires educators who believe in this way of thinking and feel capable to teach according to the NE motifs. An important concept related to this belief is Self-Efficacy, which refers to individuals' judgment of their capabilities to organize and execute courses of action required to achieve desired performances (Bandura, 1997).

"Teacher self-efficacy" (TSE) refers to the teachers' beliefs in their capability to organize and execute courses of action required to successfully accomplish a specific teacher task in a particular context (Tshene-Moran \& Woolfolk-Hoy, 2001). This factor represents the affective component of their attitudes (Rosenberg \& Hollande, $1960)$ in regard to using motifs from neuroeducation in pedagogical techniques. Research on self-efficacy has implications for the advancement of neuroeducation because there is a reciprocal relationship between teachers' self- efficacy and their instructional qualities (Holzberger, Philipp \& Kunter, 2013; Murphy, 2017). Since TSE can impact their motivation, planning, and competency, and in turn influences behavior, it can also impact teachers' performance (Bandura \& Adams, 1977; Tschannen-Moran \& Woolfolk Hoy, 1998). In addition, according to Tunks and Weller (2009), a successful course of change entails that people restructure their patterns of behavior, key beliefs about themselves and their abilities.

\section{Attitudes toward introducing change}

One of the main NE field's purposes is to suggest new evidence-based teaching methods. Educational systems are currently under pressure to implement changes and achieve greater efficiency (Avidov-Ungar \& ForkoshBaruch, 2018; Ferrari, Mura, \& Diamantini, 2018; Fullan, 2007; Maskit, 2011). The burden of implementing such changes has shifted from the administration to the teachers. Introducing and implementing pedagogical changes involve great difficulties, particularly in cases in which educational reform is not introduced by the same unit expected to implement the changes (Fullan, 2007; Mariage \& Garmon, 2003). An example for this can be seen In Israel. The Israeli Ministry of Education introduced a national program termed "Israel moves to a Higher Grade" in which innovative pedagogy is employed to create meaningful learning. This trend has been integrated in the colleges of education, in which teachers and educators strive to influence pre-service teachers to pursue their roles as leaders (Avidov-Ungar \& ForkoshBaruch, 2018). While the Israeli Ministry of Education officially certified that the program should be implemented, the in-service teachers in schools are expected to implement it and the pre-service teachers are expected to receive the appropriate training on the integration of the new program in their practice. The implementation process sometimes causes frustration and confusion among the Israeli pre-service teachers. Exploring the teachers' attitudes toward change might offer valuable insights on the dynamic of their readiness and preparedness to accept and implement a new program.

Attitude is a psychological construct, a mental and emotional entity that inheres in, or characterizes a person (Allport, 1935; Perloff, 1993). An attitude consists of three components: cognitive, affective and behavioral (Rosenberg \& Hovland, 1960). Attitudes form and change in three contexts: the person, social relationships, and 
sociohistorical/ sociopolitical occurrences (Albarracin \& Shavitt, 2018). Maskit (2011) researches in-service teachers' attitudes toward change, and suggests further examination of the various effects of teachers' professional development on their attitudes toward pedagogical changes - changes regarding different teaching strategies concerning students, teaching content, and the teacher's own educational orientation.

Teachers' attitudes were researched widely and in different contexts. However, only few studies examined teachers' attitudes regarding neuroeducation. Pickering and Howard-Jones (2007) reported educators' enthusiasm for neuroeducation from a sample of teachers attending neuroscience professional development courses. Following these promising results, Serpati and Loughan (2012) expanded the findings into a questionnaire to assess the teachers' perceived importance of neuroeducation and reached similar results.

While Serpati and Loughan (2012) assessed the importance of understanding scientific contents from the NS field in education and teaching and the importance of combining NS in education and teaching in their questionnaire, there was no reference to the issue of teachers' roles regarding combining NS in education. According to Phillippo and Stones (2013), teacher roles, implying what is expected from them as professional teachers, have tended to focus on the curricular instruction within classrooms, but may have wider implications and are critical to teacher characteristics related to their ultimate practice. Therefore, our study takes into account the teacher's role regarding combining NS in education, teaching and learning. This factor can also represent the cognitive component of their attitudes (Rosenberg \& Hovland, 1960) regarding using motifs from neuroeducation in education and teaching.

Readiness for change equates to a preparation stage, whereby individuals have positive attitudes toward a change and indicate an inclination to act in the immediate future. Thus, one crucial element of the readiness to make such changes is the attitude of individual administrators and teachers regarding the change. Moreover, readiness for change requires the willingness to change (Holt \& Vardaman, 2013). Maskit (1998) defined the different factors, which influence teachers' attitudes toward the introduction of changes in teaching methods. One of the factors is teachers' willingness to invest time in introduction of changes in their teaching methods. The author defined this factor as the amount of time the participants are willing and ready to invest in practice. In this study, this factor represents the behavioral component of their attitudes (Rosenberg \& Hovland, 1960) regarding using motifs from neuroeducation in education and teaching, and according to the literature a positive correlation between teachers' willingness to invest time in introduction of change and attitudes toward the change is expected.

From the summary of the literature above, a gap in knowledge concerning TSE and teachers' attitudes regarding neuroeducation implementation is revealed. Therefore, the aim of this study is to explore which factors may explain the variance in pre-service teachers' attitudes regarding using motifs from neuroeducation in their education and teaching practice.

\section{The research hypotheses}

1) Pre-service teacher's perceived roles regarding combining NS in education, teaching and learning and the amount of time they are willing to invest in introduction of changes in their teaching methods will significantly explain the variance in attitudes towards change (combining knowledge from NS research in education).

2) Pre-service teacher's self-efficacy in combining NS knowledge in education, teaching and learning will significantly explain the variance in attitudes towards change (combining knowledge from NS research in education); higher selfefficacy is related to more positive attitudes.

\section{Research Methodology}

\section{Research participants and design}

The participants were pre-service teachers in their $2^{\text {nd }}$ year of studies in the special education track, from two teacher-training colleges in the center of Israel. Ninety pre-service teachers participated in a Neuroeducation Training Program (NTP) during a reading course in the academic year of 2017-2018. During the program, motifs and teaching methods from NS were implemented in a reading course. The participants were requested to complete an online battery of questionnaires at two time points: before and after the training program. Thirty-three participants $(36 \%$ response rate) completed the entire battery of questionnaires and were included in the current analyses. Their age ranged between 19 to 57 (mean = 24.8, $S D=6.19), 32$ female and one male. 


\section{Program's description}

The NTP is an intervention program for pre- service teachers in which motifs from NS were implemented during a reading class. The aims of the NTP were to present an innovative research field for the future teachers, to present evidence- based teaching methods for practice in class and modeling interdisciplinary teaching by implementing neuroscience motifs within another course. The intervention program included ten lessons, each focused on a subject, such as neuromyths, neuroplasticity, mirror neurons, brain and reading and spaced learning. Two main motifs were chosen which were studied in-depth throughout the program: learning in context and metacognition. Each concept from the NS field was connected to the themes studied in the reading course by the lecturers. Three lecturers, including the main researcher of the study, taught the lessons of the intervention program, according to a standard syllabus and lesson plans.

\section{Research tools}

The research tool package included five online questionnaires. The questionnaires were adapted for usage in the Hebrew language and validated psychometrically for the present research in an expert validation procedure and tested in a pilot study with 19 participants for reliability tests (Luzzatto \& Rusu, 2018).

1. Teacher Self- Efficacy scale (based on TSES, Tscannen-Moran \& Woolfolk Hoy, 2001). This scale includes 24 items. Strong agreement (5) represents students' strong beliefs that they have high abilities and competence in education and teaching. The overall reliability of the scale is very high $(\alpha=.97)$.

2. Teacher self-efficacy questionnaire (based on Lazar, 2014). This scale includes 19 items out of the original 25 items of the scale. Strong agreement (5) represents high teacher's selfefficacy. The overall reliability of the scale was high $(\alpha=.89) .6$ items that relate to self-efficacy regarding combining NS in education were added to the original scales and their reliability was tested separately. General SE in education and teaching had a value of $\alpha=85$, and $\mathrm{SE}$ in combining NS in education and teaching and learning had a value of $\alpha=.80$.
3. Attitudes toward change questionnaire (based on Priester \& Petty, 1996, in Zach, 2012). This scale includes six items (out of the original 18 items of the scale: The Strong agreement (5) represents positive attitude towards change - combining knowledge from NS research in in education and teaching. The overall reliability of the scale is acceptable $(\alpha=.763)$.

4. Teacher attitudes of neuroeducation questionnaire (based on Serpati \& Loughan, 2012). This questionnaire includes three subscales: Sub-scale 1 - The importance of understanding scientific contents from the NS Field in education and teaching. This sub-scale includes ten items. A high score (5) represents high importance related to understanding scientific content from the NS field. The overall reliability of the scale is good $(\alpha=.80)$. Sub-scale 2: The Importance of Combining NS in Education and Teaching - This sub-scale includes five items. A high score (5) represents high importance related to combining NS in education. The overall reliability of the scale was $\alpha=.73$. Sub-scale3: Teachers' Roles regarding Combining NS in Education - This sub-scale includes five items. Strong agreement (5) represents a positive attitude towards change combining knowledge from NS research in education. The overall reliability of the scale was high $(\alpha=.86)$.

5. Attitudes toward the introduction of changes in teaching methods questionnaire (based on Maskit, 1998): Four sub-scales were identified in this questionnaire: Sub-scale 1: Attitudes toward changes in teaching methods: Cognitive and affective aspects -This sub-scale includes nine items (out of the original 14 items of the original sub- scale). A high score (5) represents strong agreement with each statement related to introduction of changes into teaching methods. The overall reliability of the scale is high ( $\alpha$ Cronbach $=.85)$. Sub-scale 2: Attitudes toward changes in teaching methods: Willingness aspect- This sub-scale includes ten items. A high score (5) indicates that the respondent is very willing to invest time in introduction of changes in his/her teaching methods. The overall reliability of the scale was high $(\alpha$-Cronbach $=$ 
.79). Sub-scale 3: Factors That May Assist in Introduction of Change Processes- This subscale includes all original nine items. Strong agreement (5) represents high impact (assistance) of each factor on the introduction of the process of change. The overall reliability of the sub-scale is acceptable ( $\alpha$ Cronbach $=.77)$. Sub-scale 4:
Teacher perceptions. This sub-scale includes five items which are focused on teachers' perception of teaching as evidence based. Strong agreement (5) represents a strong belief that teaching should be an evidence- based profession. The overall reliability of the sub-scale is acceptable $(\alpha=.72)$.

\section{Results}

Results are presented according to the variables connected to the implementation of NS in education (table no. 1).

Table no. 1. Descriptive statistics of the research variables

\begin{tabular}{|c|c|c|c|c|}
\hline & Minimum & Maximum & Mean & SD \\
\hline (1) Attitudes towards change - Combining knowledge from NS research in education & 3.00 & 5.00 & 4.24 & 0.55 \\
\hline (3) Pre-service teachers' Self Efficacy-NS knowledge & 1.75 & 4.50 & 3.23 & 0.81 \\
\hline (8) Pre-service teachers' beliefs about their abilities and competences (SE) & 3.04 & 5.00 & 4.03 & 0.52 \\
\hline (2.1) Understanding scientific content from NS field is important for the following topics & 2.70 & 5.00 & 4.16 & 0.63 \\
\hline (2.2) The importance of combining NS in education & 1.80 & 5.00 & 3.78 & 0.81 \\
\hline (2.3) Pre-service teachers' roles regarding combining NS in education & 2.00 & 5.00 & 3.87 & 0.75 \\
\hline (4) Attitudes towards introducing change in teaching methods & 2.33 & 4.78 & 3.85 & 0.56 \\
\hline $\begin{array}{l}\text { (5) The amount of time Pre-Service teachers are willing to invest in introducing of changes in their } \\
\text { teaching methods }\end{array}$ & 2.80 & 5.00 & 3.95 & 0.58 \\
\hline (6) Factors that may assist in introducing change processes & 2.22 & 5.00 & 3.35 & 0.73 \\
\hline (7) Pre-service teachers' attitudes toward evidence -based teaching & 2.60 & 5.00 & 3.75 & 0.75 \\
\hline
\end{tabular}
$\mathrm{N}=33$

The results of the multiple regression analysis for explaining the variance in the criteria are presented in figure no. 1.

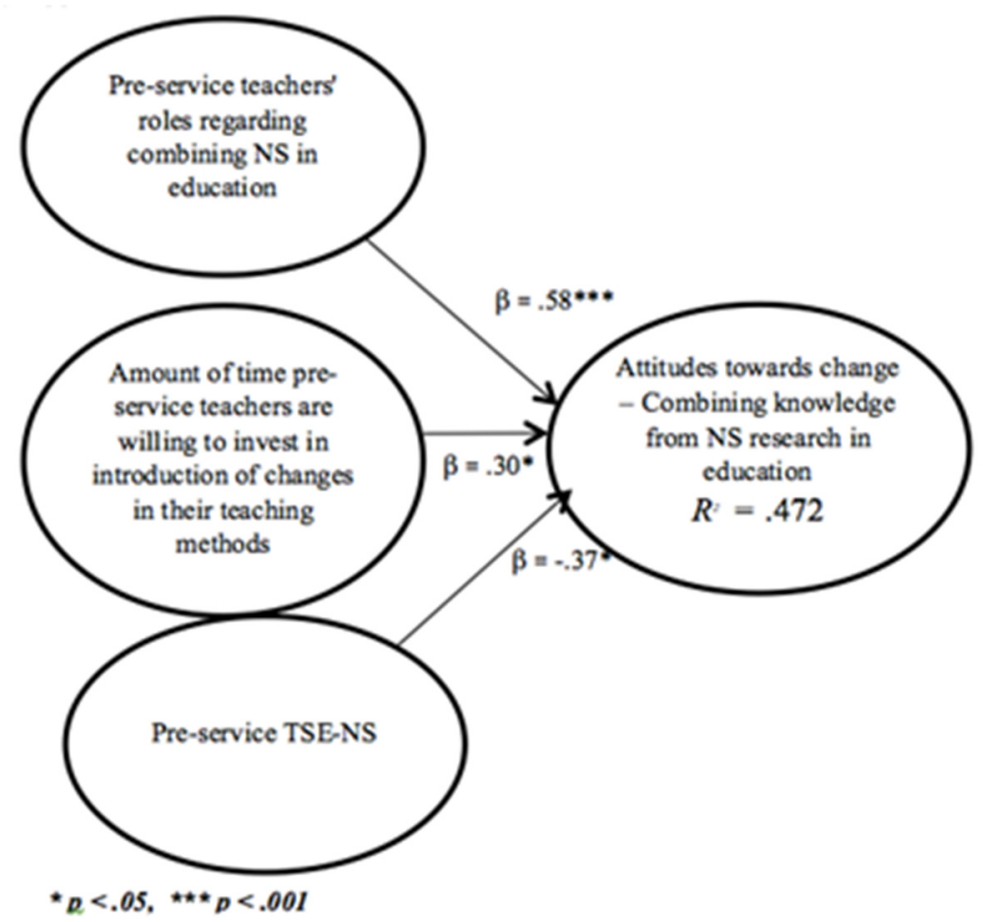

Figure no. 1. Multiple regression analyses performed for explaining the variance in pre-service teachers' attitudes towards including concepts from NS in their pedagogical practice

According to the data analysis, $47.2 \%$ of the variance in PSTs' attitudes towards combining concepts from 
neuroeducation in education and teaching is significantly explained by teachers' roles regarding combining NS in education $(\beta=.58, p=.001)$, the amount of time PSTs are willing to invest in introduction of changes in their teaching ( $\beta=.30, p=.042$ ) and TSE regarding using concepts from neuroeducation in education and teaching ( $\beta=-.37, p=.017)$. In other words, the more the PSTs' agreed with their roles regarding combining NS in education, the more time they are willing to invest in introduction of changes in their teaching, and the less stronger is their self-efficacy regarding the use of concepts from neuroeducation in education and teaching - the level of favorability of the attitudes towards change - combining knowledge from NS research in education and teaching is higher. Therefore, the first hypothesis was confirmed, while the second hypothesis was refuted.

\section{Discussions and conclusions}

The aim of this study was to explore which factors may explain the variance in PSTs' attitudes towards introducing change, i.e. using concepts from neuroeducation in their pedagogical practice. The variables targeted in this research correspond to the three components of the attitudes (Rosenberg \& Hovland, 1960): cognitive, affective and behavioral. The PSTs' roles regarding combining NS in education deal with the pre-service perceptions of roles and represent the cognitive component. The amount of time PSTs are willing to invest in introduction of changes in their teaching may represent the behavioral component of the attitude, and the pre-service TSE relating implementation of neuroscience in education may represent the affective component.

The Israeli PSTs' perceived roles regarding combining NS in education, teaching and learning and the amount of time they are willing to invest in the introduction of changes in their teaching methods will significantly explained the variance in attitudes towards change (combining knowledge from NS research in education). Their perceptions of the teacher's roles as central and their willingness to invest more time in introduction of change in their pedagogical methods was related to more favorable attitudes. Several possible implications emerge from the findings. Since a positive correlation was found between perceptions of the teacher's role as central and favorable attitudes toward introduction NS in teaching, a future NS teacher training program should take this finding into consideration in the planning stage. Thus, the professional identity of the teacher as a professional should also be considered to reinforce the understanding that scientific professional knowledge of teaching and learning mechanisms may contribute to being a better teacher and increase the understanding of the way students learn.

Regarding the finding that the amount of time PSTs are willing to invest in introduction of changes in their teaching methods was positively correlated with attitudes toward implementation of change, a possible implication of this might be for the education decision-makers and policymakers. The findings support the idea that it is important to allocate time for teachers to examine practices in introducing changes in their teaching and allow them the space and time resources.

While the first two components were positively associated with the attitude toward change in implementing NS in education, the TSE component was associated in a negative connection. The second hypothesis, i.e. pre-service TSE in combining NS knowledge in their pedagogical methods will significantly explain the variance in attitudes towards change (combining knowledge from NS research in education), was refuted in this study. This finding was surprising in regards to previous studies, since according to the literature, teachers' high or low efficacy may influence levels of change's implementation (Stanton, Cawthon, \& Dawson, 2018), and that change-related self-efficacy proved to be a solid predictor for positive attitudes and behavior in organizational changes (Zala-Mezö, Raeder, \& Strauss, 2019).) In their study from 2013, a number of 700 elementary school teachers were surveyed; the data indicated a positive association between self-efficacy and attitudes toward change. In general, teachers with high levels of self-efficacy were reported as being more open to the idea of changing their practices (Brenner, 2013). However, contradictory findings can also be found in the literature. Lee, Cawthon, and Dawson (2013) posed the question: how does high teacher self-efficacy relate to pedagogical conceptual change? Results indicated that self-efficacy was not necessarily predictive of greater integration of a suggested change in the teaching methods. Rather, some teachers with high self-efficacy were found to implement at higher levels while others 
were not. The authors suggested an explanation to this finding, by saying that personal stressful events, such as getting married or leaving home might influence TSE at specific time periods. This might also be a possible explanation for this finding in this study, since the preservice teachers in their second year of studies sometimes experience significant life events. Thus, although they have positive attitudes toward implementing neuroscience motifs in education, they do not feel they have the efficacy to do so.

In conclusion, this study contributes to knowledge in several levels: theoretical, methodological and practical. On the theoretical level, this study expands the knowledge concerning implementation of motifs from the field of neuroeducation in education and teaching pre-service teachers, by focusing on the psycho- social characteristics of those who are expected to implement changes in teaching methods in the future. Also, this study sheds light on the factors that influence attitudes towards change with

\section{Authors note:}

The authors have equal contributions to this article.

Efrat Luzzatto is a pedagogical instructor and a lecturer in the special education track in one of the main teacher training institutes in Israel. She is a PhD student in BabesBolyai University, Cluj-Napoca, Romania. Her research areas are aimed to develop and explore an intervention program (NTP) that implement motifs from neuroscience in a reading course. She teaches courses in learning disabilities, reading accommodations for students with special needs and constructing intervention programs for students with learning disabilities.

Alina S. Rusu (biologist and psychologist) is currently an Associate Professor in the Department of Special Education, School of Psychology and Educational Sciences, Babes-Bolyai University, Cluj-Napoca, Romania and member of the Doctoral School "Education, Reflection, Development" (domain: Psychology). Her professional and research interests are: humane education, interdisciplinary curriculum development, applied values of human-animal interactions and the multidimensional study of community-oriented volunteering. She teaches courses in animal psychology, the emphasis on combining knowledge from NS research in education and challenge the connection between selfefficacy and attitudes. On the methodological level, the research offers a new valid and reliable package of questionnaires examining TSE and attitudes toward change, both general and specific to implementation of NS in education. In terms of applied values, the research results may contribute in constructing training programs dealing with neuroeducation in other countries and cultures. Such programs should not only promote the importance of evidence-based teaching and may change teaching methods but will also pay attention to psychosocial characteristics of the people involved in the implementation of such a change. Also, longitudinal studies, which involve more support to teachers implementing change and perhaps more detailed observations should be conducted in order to better understand the impact of innovative teacher training programs on attitudes toward change and TSE concepts.

psychobiology of human sexuality, and positive psychology applied to inclusive institutions.

\section{References}

Albarracin, D., \& Shavitt, S. (2018). Attitudes and attitude change. Annual review of psychology, 69, 299-327.

Allport, G. (1935). Attitudes. In C. Murchison (Ed.), Handbook of Social Psychology (pp. 789-844). Worcester, MA: Clark University Press.

Ansari, D., De Smedt, B., \& Grabner, R. H. (2012). Neuroeducation - a critical overview of an emerging field. Neuroethics, 5(2), 105-117.

Avidov-Ungar, O., \& Forkosh-Baruch, A. (2018). Professional identity of teacher educators in the digital era in light of demands of pedagogical innovation. Teaching and Teacher Education, 73, 183-191.

Bandura, A., \& Adams, N.E. (1977). Analysis of self-efficacy theory of behavioral change. Cognitive Therapy and Research, 1(4), 287-310.

Bandura, A. (1997). Self-efficacy. Harvard Mental Health Letter, 13(9), 4. Available at: http://search.ebscohost.com.ezproxy.levinsky.ac.il/login.asp $\mathrm{x}$ ?direct $=$ true $\& \mathrm{db}=$ aph $\& \mathrm{AN}=9703260522 \&$ site $=$ ehost-live (accessed at 23.11.2019).

Blakemore, S. J., \& Frith, U. (2005). The learning brain: Lessons for education. Oxford, UK: Blackwell.

Brenner, K. (2013). The Relationship between elementary general education teachers' self-efficacy and attitude toward change. Northern Arizona University. ProQuest, UMI Dissertations Publishing. 
Devonshire, I.M., \& Dommett, E.J. (2010). Neuroscience: Viable application in education?. Neuroscience and Society, 16, 349-356.

Ferrari, M., Mura, G., \& Diamantini, D. (2018). Digital innovation in education: Occupational stress and attitude toward change among schoolteachers. American Journal of Educational Research, 6(2), 142-148.

Fullan, M. (2007). The new meaning of educational change (4th edition). New York: Teachers College Press.

Holzberger, D., Philipp, A., \& Kunter, M. (2013). How teachers' self-efficacy is related to instructional quality: A longitudinal analysis. Journal of Educational Psychology, 105(3), 774-786.

Holt, D.T., \& Vardaman, J.M. (2013). Toward a comprehensive understanding of readiness for change: The case for an expanded conceptualization. Journal of Change Management, 13(1), 9-18.

Lazar, R. (2014). The influence of expressive arts group- work on developing self-efficacy and empathy to fortify the teacherpupil relationship. Doctoral dissertation. Professional School of Psychology, Sacramento. Available from Levinsky Dissertations and Theses database. (Publication/Order No. 371.102).

Lee, B., Cawthon, S., \& Dawson, K. (2013). Elementary and secondary teacher self-efficacy for teaching and pedagogical conceptual change in a drama-based professional development program. Teaching and Teacher Education, 30, 84-98.

Luzzatto, E., \& Rusu, A.S. (2018). Teacher self- efficacy, attitudes toward change and neuroeducation perception: Tool package development. Education, Reflection, Development - Sixth Edition of the Education, Reflection, Development Conference 2018, Cluj- Napoca, Romania.

Maskit, D. (1998). Teachers ' attitudes towards introduction of changes into teaching methods: The perception of teaching as a profession and stages in the professional development. (Doctoral Dissertation.). Hebrew, University of Haifa, School of Education, Department of Education.

Maskit, D. (2011). Teachers' attitudes toward pedagogical changes during various stages of professional development. Teaching and Teacher Education, 27(5), 851-860.

Mariage, T.V., \& Garmon, M.A. (2003). A Case of educational change: Improving student achievement through a SchoolUniversity Partnership. Remedial and Special Education, 24(4), 215-234.

Meltzoff, A.N., Kuhl, P.K., Movellan, J., \& Sejnowski, T.J. (2009). Foundations for a new science of learning. Science, 325(5938), 284-288.

Murphy, S.C. (2017). The promise and pitfalls of neuroeducation as a grounding for instructional practices: An exploration of k-12 application and assessment. Graduate theses and dissertations, 19. Available at: https://pilotscholars.up.edu/etd/19 (accessed at 24.11.2019).

Nouri, A. (2013). Practical strategies for enhancing interdisciplinary collaboration in neuroeducational Studies.
International Journal of Cognitive Research in Science, Engineering and Education (IJCRSEE), 1(2), 94-100.

Perloff, R.M. (1993). The dynamics of persuasion: Communication and attitudes in the 21st century. Lawrence Erlbaum Associates: Cleveland State University

Phillippo, K.L., \& Stone, S. (2013). Teacher role breadth and its relationship to student-reported teacher support. High School Journal, 96(4), 358-379. Available at: https://doiorg.ezproxy.levinsky.ac.il/10.1353/hsj.2013.0016 (accessed at 25.11.2019).

Pickering, S.J., \& Howard-Jones, P. (2007). Educators' views on the role of neuroscience in education: Findings from a study of UK and international perspectives. Mind, Brain, and Education, 1(3), 109-113.

Rodgers, D.L. (2015). The biological basis of learning: Neuroeducation through simulation. Simulation \& Gaming, 46, 175-186.

Rosenberg, M.J., Hovland, C.I., McGuire, W.J., Abelson, R.P., \& Brehm, J.W. (1960). Attitude organization and change: An analysis of consistency among attitude components. (Yales studies in attitude and communication.). Oxford, England: Yale University Press.

Serpati, L., \& Loughan, A.R. (2012). Teacher perceptions of neuroeducation: a mixed methods survey of teachers in the United States. Mind Brain and Education, 6(3), 174-176.

Stanton, K., Cawthon, S., \& Dawson, K. (2018). Self-efficacy, teacher concerns, and levels of implementation among teachers participating in drama-based instruction professional development. Teacher Development, 22(1), 51-77.

Tschannen-Moran, M., Hoy, A.W., \& Hoy, W.K. (1998). Teacher efficacy: Its meaning and measure. Review of Educational Research, 68(2), 202-248.

Tschannen-Moran, M., \& Hoy, A.W. (2001). Teacher efficacy: Capturing an elusive construct. Teaching and Teacher Education, 17(7), 783-805.

Tunks, J., \& Weller, K. (2009). Changing practice, changing minds, from arithmetical to algebraic thinking: An application of the concerns-based adoption model (CBAM). Educational Studies in Mathematics, 72, 161-183.

Van der Linden, W., Bakx, A., Ros, A., Beijaard, D., \& van den Bergh, L. (2015). The development of student teachers' research knowledge, beliefs and attitude. Journal of Education for Teaching, 41(1), 4-18.

Zach, S. (2012). Emdot morim klapei shinooi bemaarechet hahinuch vedarchei yisoom refotmat "ofek hadash" bekerev morim lehinooch goofani [Teachers' attitudes to changes in the education system and forms of implementation of the "Ofek Hadash" reform plan among physical education teachers]. Research Paper. Tel Aviv: Mofet Press.

Zala-Mezö, E., Raeder, S., \& Strauss, N.C. (2019). More knowledge helps implement change: Evaluation of a training program during educational reform. Studies in Educational Evaluation, 61, 105-111. 